\title{
Evaluation of the chemical composition of Dacryodes edulis (G. Don) seeds
}

\author{
C. O. UJOWUNDU ${ }^{1 *}$, F. N. KALU ${ }^{2}$, O. E. OKAFOR ${ }^{2}$, N. C. AGHA ${ }^{1}$, C. S. ALISI ${ }^{1}$ and \\ R. N. NWAOGUIKPE ${ }^{1}$ \\ ${ }^{1}$ Biochemistry Department, Federal University of Technology Owerri, Imo State, Nigeria. \\ ${ }^{2}$ Biochemistry Department, University of Nigeria Nsukka, Enugu State, Nigeria. \\ ${ }^{*}$ Corresponding author, E-mail: ujowundu@yahoo.com
}

\begin{abstract}
The Chemical composition and the effect of heat treatment on seeds of Dacryodes edulis (G.Don) were studied. In the proximate analysis, the moisture $(42.63-48.05 \%)$ and carbohydrate $(35.94-38.35 \%)$ values were the highest. The values of the tannins $(21.80-25.77 \%)$, alkaloids $(10.40-10.60 \%)$ and saponins $(5.92$ $6.72 \%)$ were higher than the other phytochemicals measured. Potassium $(9.0 \pm 0.005-11.00 \pm 0.10 \mathrm{mg} / 100 \mathrm{~g})$, calcium $(2.23 \pm 0.006-5.88 \pm 0.005 \mathrm{mg} / 100 \mathrm{~g})$ and phosphorus, $(1.09 \pm 0.05-2.01 \pm 0.5 \mathrm{mg} / 100 \mathrm{~g})$ were the predominant elements present in the seeds. Sodium, magnesium, selenium, zinc and iron were present in appreciable amounts but manganese was not detected. The ascorbic acid and vitamin A contents were (18.79 \pm $0.81-25.76 \pm 1.51 \mathrm{mg} / 100 \mathrm{~g})$ and $(1.12 \pm 0.04-1.64 \pm 0.01 \mathrm{mg} / 100 \mathrm{~g})$ respectively. The results of this study showed that $D$. edulis seeds are potential source of essential nutrients to man and animal when properly processed.
\end{abstract}

(C) 2010 International Formulae Group. All rights reserved.

Keywords: Food, phytochemical, chemoprotective, antioxidant, cofactor, deficiency, radical.

\section{INTRODUCTION}

Dacryodes edulis (G.Don) (African pear) belongs to the family Burseracea and has many medicinal and nutritional uses (Burkill, 1985). D. edulis is consumed traditionally in Nigeria either raw, roasted or boiled in hot water. It is eaten alone, or used in garnishing fresh maize (Arisa and Lazarus, 2008). It is widely found in many sub-Saharan countries such as Nigeria, Liberia, Cameroon and Zaire (Boungou, et al., 1991), and it may be available for up to 6 months of the year (Eka, 1977; Lam, 1985; Omoti and Okiy, 1987). The nutritional value of the fruit lies in its edible mesocarp which is rich in fatty acids, amino acids and ascorbic acid (Omoti and Okiy, 1987; Kapseu and Tchiegang, 1996; Leakey, 1999). The fruits could also provide vegetable oils for the food, pharmaceutical and cosmetic industries (Fonteh, 1998; Kapseu, et al., 2002; Mbofung, et al., 2002; Kalenda, et al., 2002). According to Gunstone and Norris (1982), the seeds of the fruit contain up to $18-70 \%$ oil. This makes the seed to compare favorably with other oil bearing seeds such as palm kernel (40\%), peanuts (49\%), cotton seed (36\%), and soybean (20\%) (Abraham and Hron, 1992; Arisa and Lazarus, 2008). The consumption pattern usually involves discarding the seeds 
after the consumption of the mesocarp or pulp (Ajayi and Oderinde, 2002). Obasi and Okolie (1993) in their study showed that the seeds can be used as food supplement. Traditionally, D. edulis are gathered for household use or for sale in local markets, but increasingly, some enter national and international trade in significant quantities (Awono, et al., 2002). As a result of this, the fruits may provide means to reduce poverty and enhance food security. Research on the use and commercialization of indigenous fruits shows that they can effectively raise the income of the poor within sustainable land use systems (Schreckenberg, et al., 2002). A major problem faced by $D$. edulis is that of possible extinction due to large-scale deforestation of the tropical forests. This is because the species has not been widely cultivated in plantations. The existing stands are mainly from traditional agroforestry systems (Leakey, 2001; Akachuku, 2006).

This study will evaluate the nutritional composition of $D$. edulis seeds and the effect of heat treatment. The results are expected to expose the nutritional potentials and thereby increase the usage in human and animal food supplementation in the future.

\section{MATERIALS AND METHODS}

\section{Plant sample collection and preparation}

The ripe fruits of $D$. edulis used for the study were obtained from Ihiagwa market in Owerri-West LGA, Imo-State Nigeria. They were identified by Dr. A.C. Ibe, a plant taxonomist in the Department of Crop Science, Federal University of Technology Owerri, Nigeria. The ripe fruits were washed thoroughly and then divided into two groups. The pulp of one group was removed raw and the other group was boiled before removing the pulp. The seeds were allowed to dry at room temperature. The dried seeds were ground to fine powder with an electric grinder, packaged in air-tight glass jar and stored at room temperature until analysis was carried out.

\section{Phytochemical test}

Phytochemical test for the quantitative determination of alkaloids, flavonoids, tannins, saponnis, cyanogenic glycosides were done by methods described by Harborne (1973) and Trease and Evans (1989).

\section{Proximate analysis}

The proximate composition of the seeds for carbohydrate, ash, and moisture were determined by methods described by AOAC (1995). Crude protein, fibre and fat content were determined by methods described by Pearson (1976). Total ash content was determined by furnace incarnation using the method of James (1995). All determinations were done in triplicates.

\section{Vitamin and mineral analysis}

Vitamins $\mathrm{A}$ and $\mathrm{C}$ were determined by High Performance Liquid Chromatography (HPLC, model CO30). Sodium and potassium were determined by digital flame photometer (model 2655-00). The other minerals; calcium (Ca), phosphorous (P), magnesium ( $\mathrm{Mg})$, manganese $(\mathrm{Mn})$, iron $(\mathrm{Fe})$, zinc $(\mathrm{Zn})$ and selenium (Se) were determined using the atomic absorption spectrophotometer (AASmodel-Alpha 4) as described by AOAC (1995).

\section{Statistical analysis}

The results obtained are presented as mean \pm standard deviation and some as simple percentages. Microsoft Excel package was used for the analysis of variance (ANOVA) and for the test of significance between means $(\mathrm{p}<0.05)$.

\section{RESULTS}

The results of the proximate composition of the raw and heat treated $D$. 
edulis seeds are shown in Table 1. Relative to the raw seeds, the heat treatment decreased ( $\mathrm{p}$ $<0.05$ ) the moisture content from $48.05 \%$ to $42.63 \%$. Similarly the ash, ether extract and carbohydrate decreased $(\mathrm{p}<0.05)$ after the heat treatment. However, the crude protein and crude fibre contents increased $(p<0.05)$ after heat treatment.

The results of the phytochemical analysis are shown in Table 2. The phytochemical content showed that alkaloids $(10.40-10.60 \%)$ had the highest value and cyanogenic glycosides $(0.42-1.71 \%)$ had the lowest. The alkaloids, flavonoids, saponins, cyanogenic glycosides and tannins decreased $(p<0.05)$ after the heat treatment.

The results of the mineral contents of the raw and heat treated seeds are shown in
Table 3. From the result, potassium $(9.0 \pm$ $0.005-11.00 \pm 0.10 \mathrm{mg} / 100 \mathrm{~g}$ ) had the highest value followed by calcium $(2.23 \pm 0.006$ $5.88 \pm 0.005 \mathrm{mg} / 100 \mathrm{~g})$ and phosphorus $(1.09 \pm$ $0.05-2.01 \pm 0.5 \mathrm{mg} / 100 \mathrm{~g})$. Zinc $(0.011 \pm 0.04$ $-0.022 \pm 0.05 \mathrm{mg} / 100 \mathrm{~g})$ and iron $(0.003 \pm$ $0.01-0.012 \pm 0.03 \mathrm{mg} / 100 \mathrm{~g}$ ) had the lowest values. Minerals such as sodium, magnesium, selenium were present in appreciable amounts but manganese was not detected. The concentration of the minerals decreased $(p<0.05)$ after the heat treatment.

The results of the vitamin contents are shown in Table 4. The ascorbic acid (18.79 \pm $0.81-25.76 \pm 1.51 \mathrm{mg} / 100 \mathrm{~g})$ and the vitamin A $(1.12 \pm 0.04-1.64 \pm 0.01 \mathrm{mg} / 100 \mathrm{~g})$ values of the seeds decreased $(p<0.05)$ after the heat treatment.

Table 1: Proximate composition (\%) of seeds of Dacryodes edulis.

\begin{tabular}{lrr}
\hline Nutrients & Raw & Treated \\
\hline Moisture & $48.05 \pm 0.50^{\mathrm{a}}$ & $42.63 \pm 0.60^{\mathrm{b}}$ \\
Ash & $1.65 \pm 0.05^{\mathrm{a}}$ & $1.35 \pm 0.05^{\mathrm{b}}$ \\
Crude protein & $4.94 \pm 0.04^{\mathrm{a}}$ & $5.71 \pm 0.51^{\mathrm{b}}$ \\
Ether extract & $9.74 \pm 0.09^{\mathrm{a}}$ & $4.63 \pm 0.06^{\mathrm{b}}$ \\
Crude fibre & $2.69 \pm 0.42^{\mathrm{a}}$ & $4.33 \pm 0.06^{\mathrm{b}}$ \\
Carbohydrate & $38.35 \pm 1.01^{\mathrm{a}}$ & $35.94 \pm 0.33^{\mathrm{b}}$ \\
\hline \multicolumn{2}{l}{ Values are means \pm standard deviation of triplicate determinations. Means having different superscript in the } \\
same row are significantly different $(\mathrm{p}<0.05)$.
\end{tabular}

Table 2: Phytochemical composition (\%) of seeds of Dacryodes edulis.

\begin{tabular}{llr}
\hline Phytochemical & Raw & \multicolumn{1}{c}{ Treated } \\
\hline Alkaloids & $10.60 \pm 0.01^{\mathrm{a}}$ & $10.40 \pm 0.05^{\mathrm{b}}$ \\
Flavonoids & $4.00 \pm 0.10^{\mathrm{a}}$ & $3.00 \pm 0.05^{\mathrm{b}}$ \\
Saponins & $6.72 \pm 0.24^{\mathrm{a}}$ & $5.92 \pm 0.05^{\mathrm{b}}$ \\
Cyanogenic glycosides & $1.71 \pm 0.04^{\mathrm{a}}$ & $0.42 \pm 0.01^{\mathrm{b}}$ \\
Tannins & $25.77 \pm 0.32^{\mathrm{a}}$ & $21.80 \pm 0.12^{\mathrm{b}}$ \\
\hline
\end{tabular}

Values are means \pm standard deviation of triplicate determinations. Means having different superscript in the same row are significantly different $(\mathrm{p}<0.05)$. 
Table 3: Mineral composition (mg/100g) of seeds of Dacryodes edulis.

\begin{tabular}{lcc}
\hline Minerals & Raw & Treated \\
\hline Calcium $(\mathrm{Ca})$ & $5.879 \pm 0.03^{\mathrm{a}}$ & $2.225 \pm 0.01^{\mathrm{b}}$ \\
Phosphorous $(\mathrm{P})$ & $2.012 \pm 0.50^{\mathrm{a}}$ & $1.088 \pm 0.05^{\mathrm{b}}$ \\
Magnesium $(\mathrm{Mg})$ & $0.295 \pm 0.03^{\mathrm{a}}$ & $0.239 \pm 0.01^{\mathrm{b}}$ \\
Manganese $(\mathrm{Mn})$ & $\mathrm{ND}$ & ND \\
Iron $(\mathrm{Fe})$ & $0.012 \pm 0.03^{\mathrm{a}}$ & $0.003 \pm 0.01^{\mathrm{b}}$ \\
Zinc $(\mathrm{Zn})$ & $0.022 \pm 0.05^{\mathrm{a}}$ & $0.011 \pm 0.04^{\mathrm{b}}$ \\
Selenium (Se) & $0.181 \pm 0.05^{\mathrm{a}}$ & $0.101 \pm 0.04^{\mathrm{b}}$ \\
Potassium (K) & $11.00 \pm 0.10^{\mathrm{a}}$ & $9.00 \pm 0.05^{\mathrm{b}}$ \\
Sodium (Na) & $0.800 \pm 0.05^{\mathrm{a}}$ & $0.500 \pm 0.10^{\mathrm{b}}$
\end{tabular}

$\overline{\text { Values are means } \pm \text { standard deviation of triplicate determinations. Means having different superscript }}$ in the same row are significantly different $(\mathrm{p}<0.05) . \mathrm{ND}=$ not detected.

Table 4: The vitamin content $(\mathrm{mg} / 100 \mathrm{~g})$ of seeds of Dacryodes edulis.

\begin{tabular}{lcc}
\hline Vitamin & Raw & Treated \\
\hline Vitamin A (mg/100g) & $1.13 \pm 0.04^{\mathrm{a}}$ & $1.64 \pm 0.01^{\mathrm{b}}$ \\
Ascorbate $(\mathrm{mg} / 100 \mathrm{~g})$ & $25.76 \pm 1.51^{\mathrm{a}}$ & $18.79 \pm 0.81^{\mathrm{b}}$ \\
\hline
\end{tabular}

Values are means \pm standard deviation of triplicate determinations. Means having different superscript in the same row are significantly different $(\mathrm{p}<0.05)$.

\section{DISCUSSION}

The high moisture content of D. edulis seeds suggests that it would have poor keeping quality. This also indicates that for the seeds to be stored, they have to be dried for longer time in order to reduce the moisture content. Low moisture content is a desirable quality in food processing and preservation because low moisture content reduces food spoilage (Omotoso and Adedire, 2007). The moisture value is higher than what was reported for seeds of Irvingia gabonensis $(12.80 \%)$ and Irvingia wombolu (11.90\%) (Joseph, 1995; Tchoundjeu et al., 2005), which are used as food condiments in Nigeria and other West African countries. The moisture content is also higher than the value $(4.83-5.5 \%)$ reported by Obasi et al. (2007) for Almond nut (Terminalia catappa), another neglected nut which has been shown to be a good source of nutrient (Kochhar, 1986). The crude protein content of the raw and heat treated seeds are lower than the values reported by Obasi et al. (1993). The increase $(p<0.05)$ in the value of protein in the heat treated seeds could be attributed to denaturation (Bankhead et al., 1978; Ubbaonu and Nwosu, 2002; Giami et al., 1999). Also heat processing, especially moist heat treatment has been reported to improve the digestibility of proteins by opening up of the protein structure through denaturation (Abbey and Berezi, 1988; Anwa et al., 2007). Proteins are for growth and repair of tissues and also as an alternative energy source in the absence of carbohydrate and fats.

Our results suggest that $D$. edulis seeds are good source of carbohydrate with content of $38.35 \%$ and $35.94 \%$ for the raw and treated seeds respectively. This result agrees with the work of Mbofung et al. (2002). When compared with the neglected seeds of some plants such as Lablab purpureus $(24.48 \pm 0.32 \%)$ and Mucuna utilis 
$(26.89 \pm 0.39 \%)$ the carbohydrate content is higher but slightly lower than $40.56 \pm 1.20 \%$ for Leucaena leucocephala (Alabi and Alausa, 2006). The decrease in the ether extract from $9.74 \%$ in the raw seeds to $4.63 \%$ in the heat treated could be due to leaching occasioned by boiling (Bankhead et al., 1978). The ether extract content is within $4.3 \pm 0.2 \%$ and $7.5 \pm 0.3 \%$ obtained for $L$. purpureus and $M$. utilis (Alabi and Alausa, 2006). The decrease $(p<0.05)$ in the ash content could also be attributed to the leaching effect resulting from boiling. Our result showed that the crude fibre increased $(p<0.05)$ after the heat treatment. The increased temperature of boiling which may have resulted into the leaching and denaturing of other content resulted in the increased value of crude fibre. High crude fibre in diet is known to enhance the digestibility, decrease the blood cholesterol and reduce the risk of large bowel cancers (Anderson et al., 1995; Salvin et al., 1997). Carbohydrates and lipids are the major energy sources in human and animal diets.

The results of the phytochemical constituents are shown in Table 2. Our results showed that the heat treatment decreased $(\mathrm{p}<0.05)$ all the phytochemicals in D. edulis. Phytochemicals in freshly harvested plant foods may be destroyed or removed by processing techniques, such as cooking. For this reason, processed foods are likely to contain fewer phytochemicals and may thus be less beneficial than unprocessed foods. Absence or deficiency of phytochemicals in processed foods may contribute to increased risk of preventable diseases (Liu, 2004; Rao and Rao, 2007). Tannins have the highest content of $25.77 \%$ and $21.80 \%$ for raw and treated seeds respectively. Tannins are polyphenols and have been reported to hasten wound healing and inflamed mucous membranes (Okwu, 2004). The presence of high level of tannins could confer on the user's chemoprotective benefits (Enechi and
Odonwodu, 2003). Tannins have also shown potential for antiviral, antibacterial and antiparasitic effects. Tannins have the potential for decreasing the digestibility and palatability of proteins because they can form insoluble complexes with them (Osagie, 1998).

The alkaloids content of the seeds were relatively low, with $10.60 \%$ and $10.40 \%$ for alkaloid in raw and treated seeds respectively. Alkaloids are employed for prophylaxis of cardiac arrhythmias and for the treatment of arterial fibrillation (Adesegun and Cooker, 2001). Saponins possess a carbohydrate moiety attached to a triterpenoid or a steroidal aglycone (Sridhar and Bhat, 2007). Saponins are natural antibiotics which fight infections and microbial invasions (Okwu, 2004; Okwu and Emenike, 2006). Saponins have hypocholestrolemic properties which could give some chemoprotection against heart diseases to human consumers (Price et al., 1987). The flavonoids content were relatively low $(4.00 \%$ and $3.00 \%)$. Flavonoids are associated with free radical scavenging activity (Parke and Ioanides, 1994). The presence of flavonoids in D. edulis may confer anti-carcinogenic potential to consumers. The cyanogenic glycosides content are very low and are significantly $(p<0.05)$ affected by the heat treatment. The concentration is within the permissible level (Enechi and Odonwodu, 2003: Abu et al., 2005) and below the toxic levels given by World Health Organization (Munro and Bassir, 1969).

Our results also showed that the values of all the minerals decreased $(p<0.05)$ after the heat treatment. This decrease may be as a result of leaching (Bankhead et al., 1978) and bond breaking effects (Oliviera and Lamb, 1998; Giami et al., 1999). The most abundant minerals in the seeds of $D$. edulis are potassium $(9.0 \pm 0.005-11.00 \pm 0.10$ $\mathrm{mg} / 100 \mathrm{~g})$, calcium $(2.23 \pm 0.006-5.88 \pm$ 
$0.005 \mathrm{mg} / 100 \mathrm{~g})$ and phosphorus (1.09 \pm 0.05 $2.01 \pm 0.5 \mathrm{mg} / 100 \mathrm{~g}$ ) for raw and treated seed respectively. These values are very low when compared to that obtained from seeds of $L$. purpureus, M. utilis and L. leucocephala (Alabi and Alausa, 2006). Potassium is the principal cation of intracellular fluid and it is involved in protein synthesis. Phosphorus is required for the synthesis of nucleic acids, some proteins and a constituent of bones and enamel, and a lack of phosphorus in diet causes rickets (Fliedner and Teichman, 2000) and osteoporosis (Okwu and Emenike, 2007). Calcium is also an important constituent of bone and enamel. It activates ATPase during muscular contraction and it is important for blood coagulation (Okaka and Okaka 2001). Minerals such as sodium, magnesium, selenium, zinc, and iron were present in appreciable amount. Manganese was not detected. Potassium plays key role along with sodium in maintaining electrical potential across cell membranes and in the conduction of nerve impulses (Taylor, 2003). Sodium is associated with the regulation of acid-base equilibrium, protection against dehydration and maintenance of osmotic pressure in the body. It plays a role in the normal irritability of muscles and cell permeability (Schwart, 1975). Selenium and zinc are cofactors for glutathione peroxidase and alcohol dehydrogenase. Iron is a component of haemoglobin and ferrodoxin and also a cofactor in catalase and peroxidase enzymes (Taylor, 2003).

The results of the vitamin contents of the seeds showed that the seeds have high levels of ascorbic acid and appreciable amount of vitamin A. The ascorbic acid content of $D$. edulis seeds is higher than the seeds of Adasonia digitata (6.71 \pm 0.04 $\mathrm{mg} / 100 \mathrm{~g})$, P. africana $(0.92 \pm 0.02 \mathrm{mg} / 100 \mathrm{~g})$ and groundnut $(9.8 \mathrm{mg} / 100 \mathrm{~g})$ (Nkafamiya et al., 2007a). Vitamin A concentration is also higher in D. edulis seeds when compared with seeds of $P$. africana $(0.89 \pm 0.01 \mu \mathrm{g} / 100 \mathrm{~g})$ but lower than that of Adasonia digitata (5.26 $\pm 0.03 \mu \mathrm{g} / 100 \mathrm{~g}$ ) (Barminas et al., 1998; Nkafamiya et al., 2007). These seeds serve as foods and condiment in Nigerian diet. Ascorbic acid has antioxidant properties and can reduce the effect of tannin on iron which makes iron not available for absorption. It is also required in the hydroxylation of proline residues during collagen synthesis. The vitamin A content of the seeds, though low, can help to alleviate symptoms of vitamin A deficiency (Nkafamiya et al., 2007b). The concentrations of these vitamins can contribute to daily vitamin needs (Murray, 1998; Trumbo et al., 2004).

This study has shown that the seeds of D. edulis are good sources of phytochemicals, minerals and other essential nutrients. Therefore, proper seed processing could make it acceptable as a substitute for commonly used condiments and could be used in human and livestock feed formulations.

\section{REFERENCES}

Abu AE, Anigo KM, Bawa GS, Chindo PS, James DB, Yakubu LB. 2005. Evaluation of some traditional processing methods on the nutrient composition of in vitro protein digestibility of lima beans (Phaseolus lunatus). Nig. J. Sci. Res., 1: 65-67.

Adesegun SA, Cooker HAB. 2001. Plants Used in Traditional Medicine Against Malaria. Africana FEP; 50 - 62.

Ajayi A, Oderinde RA. 2002. Studies on the oil Characteristics of Dacryodes edulis pulp and seed. Discov Innov., 14: 20-24.

Alabi DA, Alausa AA. 2006. Evaluation of the Mineral Nutrients and Organic Food Contents of the Seeds of Lablab purpureus, Leucaena leucocephala and Mucuna utilis for Domestic Consumption and Industrial Utilization. World J. Agric. Sci., 2(1): 115-118. 
Anderson JW, Johnstone BM, Cook-Newell ME. 1995. Meta-analysis of the effects of soy protein intake on serum lipids. New Engl. J. Med., 333: 276-282.

Akachuku AE. 2006. Disappearing forests, the consequences and the challenge of sustainable development of Nigeria. Proc. For. Assoc. Niger. pp. 48-61.

Anwa EP, Auta J, Abudullahi SA, Bolorunduro PI. 2007. Effect of processing on seeds of Albizzia lebbeck: Proximate analysis and phytochemical screening. Res. J. Bio Sci., 2(1): 41-44.

AOAC. 1995. Official Methods of Analysis. Association of Official Analytical Chemists: Wastington D.C.

Arisa NU, Lazarus A. 2008. Production and refining of Dacryodes edulis "native pear" seeds oil. Afri J. Biotechnol., 7(9): 1344-1346.

Awono A, Ndoye O, Schreckenberg K, Tabuna H, Isseri F, Temple L. 2002. Production and marketing of Safou (Dacryodes edulis) in Cameroon and internationally: Market development issues. Forests, Trees and Livelihoods, 12: 125-148.

Barminas JT, Maina HM, Ali J. 1998. Nutrient contents of Prosopis africana seeds. Plant Foods Hum. Nutr., 52: 325328.

Bankhead RR, Weingartner KE, Kuntz DA, Erman JW. 1978. Effect of Sodium biocarbonate blanches on the retention of micronutrient in soy beverage. J. Ed. Sci., 43: $345-348$.

Boungou PT, Goma MJ, Qumba J. 1991. Etude de la pulpe de safou, resultants preliminaries. Tropicultura, 9(2): 61-68.

Burkill HM. 1985. A Review of Dalziel's: The useful plants of west Africa (vol. 1). Royal Botanical Garden: Kew.

Eka OU. 1977. Studies on Nutrient Composition of the Fruit of African pear. W. Afr. J. Biol. Appl. Chem., 2: 3-7.
Enechi OC, Odonwodu I. 2003. Assessment of the phytochemical and nutrient composition of pulverized root of Cissus quadrangularis. J. Biol. Res. Biotechnol., 1: 63-68.

Fonteh A. 1998. The lipid content of the African pear and black olives from some agro-ecological zones in Cameroon. In $2^{\text {nd }}$ International Workshop on African Pear Improvement and Other New Sources of Vegetable Oils, Cameroon, Kapseu C, Kayem GJ (eds). Presses Universitaires de Yaoundé; 185-192.

Giami SY, Adindu MN, Akusu MO. 1999. Effect of processing methods on the protein and other chemical constituents of fluted pumpkin (Telfaria occidentalis) and African breadfruit (Treculia Africana). Proceeding of the 23rd Annual NIFEST Conference, Abuja, Nigeria. p. $127-130$.

Gunstone FD, Norris FA. 1982. Lipids in Foods: Chemistry, Biochemistry and Technology. Publ. Robert Maxwell; 95139.

Harborne JB. 1973. Phytoemical Methods $\left(1^{\text {st }}\right.$ edn). Chapman and Hall: London; 288.

James CS. 1995. Analytical Chemistry of Food. Chapman and Hall: New York; 2025

Joseph JK. 1995. Physico-chemical attributes of wild mango (Irvingia gabonensis) seeds. Biores. Tech., 53: 179-181.

Kalenda DT, Missang CE, Kinkela T, Krebs HC, Renard CMGC. 2002. New developments in the chemical characterization of the fruit of Dacryodes edulis (G. Don) H. J. Lam. Forests, Trees and Livelihoods 12: 119-124.

Kapseu C, Tchiegang C. 1996.Composition de l'huile des fruits de deux cultivars de safou au Cameroon. Fruits 51(3):185191.

Kapseu C, Avouampo E, Djeumako B. 2002. Oil extraction from Dacryodes edulis (G. 
Don) H. J. Lam fruit. Forests, Trees and Livelihoods 12: 97-104.

Kochhar SI. 1986. Economic Botany in the Tropics. New Delhi Macmillan Company Pubs: India.

Lam HJ. 1985. Dacryodes edulis. In The Useful Plants of West Tropical Africa, Burkill WM (ed). Royal Botanic Garden: Kew; 307-308.

Leakey RRB. 1999. Potential for novel food products from agroforestry trees: a review. Food Chem., 66: 1-14.

Leakey RRB. 2001. Win:Win landuse strategies for Africa: 2. Cap-turing economic and environmental benefits with multistrata agroforests. Int. Forestry Rev., 3: 331-340.

Liu RH. 2004. Potential synergy of phytochemicals in cancer prevention: mechanism of action. J. Nutr., 134(12): 3479S-3485S.

Mbofung CMF, Silou T, Mouragadja I. 2002. Chemical characterization of Safou (Dacryodes edulis) and evaluation of its potential as an ingredient in nutritious biscuits. Forests, Trees and Livelihoods, 12: $105-118$.

Munro A, Bassir O. 1969. Oxalate in Nigeria Vegetable. West Afr. J. Biol. Appl. Chem., 12: $14-18$.

Murray A. 1998. Dietary Reference Intake for Antioxidant Nutrients. J. Am. Diet Assoc., 100: 637-640.

Nkafamiya II, Osemeahon SA, Dahiru D, Umaru HA. 2007a. Studies on the chemical composition and physicochemical properties of the seeds of baobab (Adasonia digitata). Afr. J. Biotechnol., 6(6): 756-759.

Nkafamiya II, Modibbo UU, Manji AJ, Haggai D. 2007b. Nutrient content of seeds of some wild plants. Afri. $J$. Biotechnol., 6(15): 1665-1669.

Obasi NBB, Okolie NP. 1993. Nutritional constituents of the seed of the African pear Dacryodes edulis. J. Food Chem., 43: 297-299.

Obasi NE, Umezurike EC. 2007. Functional properties and proximate composition of raw ad roasted Indian Almond nuts (Terminalia catappa) and its potentials as a substitute in soup thickening. Nig. J. Nutr. Sci., 28(1): 99-104.

Okwu DE, Emenike IN. 2006. Evaluation of the phytonutrients and vitamin contents of citrus fruits. Inter J. Mol. Med. Adv. Sci., 2(1): 1-6.

Okwu DE, Emenike IN. 2007. Nutirtive value and mineral content of different varieties of citrus fruits. J. Food Technol., 5: 105 108.

Okwu DE. 2004. Phytochemical and vitamin content of indigenous spices of southeastern Nigeria. J. Sustainable Agric. Environ., 6(1): 30 - 37.

Omokhua GE, Koyejo AO. 2009. Fruiting efficiency in Dacryodes edulis (G. Don): A case study in Ekpoma, south-south, Nigeria. Afr. J. Biotechnol., 8(8): 15521554

Omoti U, Okiy DA. 1987. Characteristics and composition of oil and cake of African pear. J. Sci. Food Agric., 38: 67-72.

Omotoso OT, Adedire CO. 2007. Nutrient composition, mineral content and the solubility of the proteins of palm weevil, Rhynchophorus phoenicis f. (Coleoptera: Curculionidae). J. Zhejiang Univ. Sci. B., 8(5): 318-322.

Osagie AU. 1998. Antinutritional factors. In Nutritional Quality of Plant Foods, Osagie AU, Eka OU (eds). Postharvest Res. Unit. University of Benin: Benin City, Nigeria; 221 - 244.

Parke DV, Ioannides C. 1994. The effects of Nutrition on Chemical Toxicity. Drug Metabolism Reviews. 26 (4): 739-765.

Pearson D. 1976. The Chemical Analysis of Food. Churchill Livingstone: Edinburgh; 3. 
Price KR, Johnson LJ, Fenwick GR. 1987. The chemical and biological significance of saponins in foods and feeding stuffs. C.R.C. Crit. Rev. Foods Sci. Nutr., 26: 27-135.

Rao AV, Rao LG. 2007. Carotenoids and human health. Pharmacol Res., 55(3): 207-216.

Salvin J, Jacobs DR, Marquart L. 1997. Whole grain consumption and chronic disease: Protective mechanisms. Nutr. Cancer, 27: 14-21.

Sanchez PA, Leakey RRB. 1997. Land use transformation in Africa: Three determinants for balancing food security with natural resource utilization. Eur. J. Agron., 7: 15-23.

Schreckenberg K, Degrande A, Mbosso C., Boli Baboulé Z, Boyd C, Enyong L, Kanmegne J, Ngong C. 2002. The social and economic importance of Dacryodes edulis (G.Don) H.J. Lam. in southern Cameroon. Forests, Trees and Livelihoods, 12: 15-40.

Schwart MK. 1975. Role of trace elements in cancer. Cancer Res., 35: 3481-3484.
Sridhar KR, Bhat R. 2007. Agrobotanical, nutritional and bioactive potential of unconventional legume - Mucuna. Livestock Research for Rural Development, 19(9): 223 - 230.

Taylor MD. 2003. Nerve Impulse Conduction and Electrical Conduction. Rothwell Press: London; 245.

Tchoundjeu Z, Atangana AR, Degrande A. 2005. Indigenous Methods in Preserving Bush Mango Kernels in Cameroon. Am. J. Appl. Sci., 2(9): 1337-1342.

Trease GE, Evans WC. 1989. Trease and Evans' Pharmacognosy: A Physician's Guide to Herbal Medicine (13th edn). Bailliere Tindall: London.

Trumbo P, Yates AA, Schlicker SA, Poss MI, 2004. Dietary reference intake for antioxidant nutrients. J. Am. Diet Asso., 101: 294-301.

Ubbaonu CN, Nwosu JN. 2002. Effect of sprouting on the antinutritional properties and amino acid profile of "Oze" (Penradesma butyraceae) nuts. Proceeding of the 26th Annual NIFEST Conference, Owerri Nigeria. 